\title{
Identifikasi Gen elF4G asal Oryza rufipogon pada Padi Varietas Inpari HDB dan Inpari Blas
}

\section{Identification of eIF4G Gene of Oryza rufipogon origin on Rice Varieties Inpari HDB and Inpari Blas}

\author{
Ifa Manzila* dan Tri Puji Priyatno \\ Balai Besar Penelitian dan Pengembangan Bioteknologi \\ dan Sumber Daya Genetik Pertanian, Bogor 16111
}

\begin{abstract}
ABSTRAK
Aksesi padi liar Oryza rufipogon diketahui memiliki gen ketahanan terhadap penyakit tungro yang telah dimanfaatkan untuk perakitan varietas padi tahan tungro khususnya terhadap rice tungro spherical virus (RTSV). Namun hingga saat ini gen pengendali sifat ketahanan tersebut belum teridentifikasi. Gen putatif yang terkait dengan sifat ketahanan terhadap RTSV sudah diidentifikasi pada varietas Utri Merah sebagai eukaryote Translation Initiation Factor 4 Gamma (eIF4G). Penelitian bertujuan mendeteksi dan mengidentifikasi gen eIF4G pada varietas-varietas Inpari HDB dan Inpari Blas menggunakan primer spesifik yang dirancang berdasarkan runutan basa nukleotida gen eIF4G varietas Utri Merah. Gen diamplifikasi dengan metode PCR dan DNA hasil amplifikasi dirunut serta dianalisis secara in silico. Ketahanan varietas Inpari HDB, Inpari Blas, dan $O$. rufipogon terhadap 3 isolat virus tungro diuji dalam percobaan rumah kaca. Pengujian dilakukan sesuai standar international rice testing nursery menurut IRRI. Kedua varietas dan O.rufipogon menunjukkan respons tahan terhadap infeksi virus tungro. PCR menggunakan primer spesifik gen eIF4G berhasil mengamplifikasi target gen berukuran $\sim 300 \mathrm{pb}$ pada 2 varietas Inpari dan tetuanya (O. rufipogon). Analisis runutan DNA gen eIF4G menunjukkan homologi mencapai $100 \%$ diantara varietas Inpari HDB, Inpari Blas, dan O. rufipogon; dan 93\% terhadap gen eIF4G varietas Utri Merah. Berdasarkan penjajaran nukleotida ditemukan delesi sebanyak 4 nukleotida dan 16 nukleotida yang berbeda antara Utri Merah dengan 2 varietas Inpari dan $O$.rufipogon. Perbedaan nukleotida tersebut mengakibatkan ada 1 delesi asam amino dan 4 asam amino yang berbeda pada 2 varietas Inpari dan $O$. rufipogon dibandingkan dengan Utri Merah.
\end{abstract}

Kata kunci: eukaryotic translation initiation factor4 gamma, gen ketahanan resesif, tungro.

\section{ABSTRACT}

Wild rice accession Oryza rufipogon is known as a source of tungro resistance genes and has been used to develop tungro resistant varieties, especially against rice tungro spherical virus (RTSV). However the genes have not been identified yet. Previously, an eukaryotic Translation Initiation Factor (eIF4G) was identified as a putative gene associated with recessive resistance gene against RTSV in Utri Merah variety. The research was aimed to detect and identify the eIF4G gene on rice var. Inpari HDB and var. Inpari Blas using specific primer that was designed based on Utri Merah eIF4G gene sequences. The resistance respons of both Inpari varieties and O.rufipogon against 3 tungro virus isolates were conducted in the green house trial. Assays were done based on international rice testing nursery according to IRRI. The eIF4G gene is amplified by PCR and the amplicon was directly sequenced, then analysed in silico. The results showed that all 3 varieties are classified as resistant against tungro virus

\footnotetext{
*Alamat penulis korespondensi: Balai Besar Penelitian dan Pengembangan Bioteknologi dan Sumber Daya Genetik Pertanian, Jalan Tentara Pelajar 3A, Bogor 16111

Tel: 0251-8337975, Faks: 0251-8338820; Surel: ifamanzila@gmail.com
} 
isolates. PCR was successfully amplified the eIF4G gene with size $\sim 300 \mathrm{bp}$ in both of varieties and their parent $O$. rufipogon. The nucleotides homology of eIF4G among those 2 varieties and $O$. rufipogon is up to $100 \%$, while the homology to Utri Merah was $93 \%$. There were 4 nucleotides deletion and 16 nucleotides differences between Utri Merah and those 2 varieties and $O$. rufipogon, respectively. Those nucleotide differences lead to deletion of 1 amino acid and 4 amino acids different between both Inpari varieties and O.rufipogon in comparison with corresponding amino acid in Utri Merah.

Key words: eukaryotic translation initiation factor 4 gamma, recessive resistance gene, tungro

\section{PENDAHULUAN}

Penyakit tungro sudah lama dikenal sebagai salah satu penyakit penting pada tanaman padi di Indonesia. Rata-rata luas serangan tungro dalam 10 tahun terakhir mencapai 10861 ha dan puso 227 ha, dengan luas serangan tertinggi terjadi pada tahun 2011 yang mencapai 16027 ha dan puso 392 ha (Ditlin 2015). Penyakit tungro merupakan penyakit yang sangat kompleks karena penyebab penyakit melibatkan dua jenis virus yang berbeda, yaitu Rice tungro bacilliform virus (RTBV; Badnavirus) dan Rice tungro sphaerical virus (RTSV; Waikavirus) (Cruz et al. 1999).

Berbagai upaya pengendalian penyakit tungro secara fisik dan kimia telah dilakukan, tetapi pengendalian dengan varietas tahan dianggap yang paling efektif (Darajat et al. 2004). Beberapa varietas padi tahan tungro sudah dilepas, seperti Tukad Unda, Tukad Petanu, Tukad Balian, Kalimas, dan Bondoyudo (Darajat et al. 2004; Ladja dan Widiarta 2012). Namun varietas tersebut bersifat spesifik lokasi (Ladja dan Widiarta 2012) sehingga tidak berkembang luas di masyarakat. Kebanyakan varietas elit yang berkembang di sentra-sentra produksi padi ialah varietas yang tidak tahan tungro. Oleh karena itu, perbaikan sifat ketahanan varietas elit perlu dilakukan.

Sumber gen tahan tungro sudah banyak diketahui dari sejumlah plasma nutfah padi lokal, seperti Cempa Siam, Cempo Nyonya, Horeng, Kangkungan, dan Mayang Terurai (BB Padi 2010), meski belum jelas mekanisme sifat ketahanannya. Aksesi padi liar Oryza rufipogon, O. officinalis, $O$. longistaminata, dan $O$. ridleyi diidentifikasi memiliki gen ketahanan terhadap tungro (Kobayashi et al. 1993; Angeles et al. 2008). Khush et al. (2004) telah menggunakan $O$. rufipogon untuk merakit varietas Matatag 9 yang tahan tungro dari hasil persilangannya dengan IR64 di Filipina. Menurut Shibata et al (2007), ketahanan yang diturunkan dari $O$. rufipogon pada Matatag 9 adalah kombinasi sifat tahan terhadap serangga vektor melalui mekanisme antibiosis dan toleransi terhadap RTSV. Di Indonesia, 2 Varietas Unggul Baru (VUB) padi (Inpari HDB dan Inpari Blas) hasil persilangan $O$. rufipogon dan IR64 juga dilaporkan tahan tungro (Manzila et al. 2013). Tetapi gen ketahanan tungro dari O. rufipogon belum diidentifikasi hingga saat ini.

Pada varietas Utri Merah yang tahan RTSV, sifat ketahanannya dikendalikan oleh gen monogenik resesif yang berlokasi pada kromosom 7 (Choi et al. 2009). Lee et al. (2010) kemudian memetakan lebih lanjut keberadaan gen resesif tersebut dan berhasil mengidentifikasi fragmen gen resesif tungro spherical virus (tsvl) berukuran $200 \mathrm{~kb}$ di kawasan antara $22.05 \mathrm{Mb}$ dan $22.25 \mathrm{Mb}$ yang berkaitan dengan gen untuk faktor inisiasi translasi 4G (Eukaryote Translation Initiation Factor 4 Gamma: eIF4G). Keterlibatan faktor-faktor inisiasi translasi tanaman dalam mekanisme gen ketahanan resesif terhadap virus patogen sudah banyak dilaporkan (Lellis et al. 2002). Hampir setengah dari 200 gen-gen resisten tanaman terhadap virus, khususnya dari genus Potyvirus, adalah gengen resesif yang mengkodekan translation initiation factors (Hwang et al. 2013). Protein eIF4G dilaporkan berinteraksi dengan genomlinked viral proteins (Vpg) dari Potyvirus yang memanfaatkan interaksi ini untuk proses infeksinya pada sel inang (Kang et al 
2005; Miyoshi et al. 2006; German-Retana et al. 2008). Gangguan pada interaksi antara faktor translasi dan Vpg Potyvirus menjadi mekanisme dasar sifat ketahanan gen-gen resesif (Leonard et al. 2000; Yeam et al. 2007).

Penelitian ini bertujuan mendeteksi dan mengidentifikasi gen pengendali faktor inisiasi translasi 4G pada varietas Inpari HDB dan Inpari Blas dari turunan O. rufipogon. Artikel ini merupakan laporan pertama terkait faktor inisiasi translasi dari $O$. rufipogon yang diduga berperan penting pada sifat ketahanan RTSV terhadap varietas Inpari HDB dan Inpari Blas.

\section{BAHAN DAN METODE}

\section{Uji Ketahanan Tanaman Padi}

Tanaman padi yang digunakan untuk identifikasi gen ketahanannya terhadap tungro ialah var. Inpari HDB, Inpari Blas dan padi liar O. rufipogon (No. aksesi IRGC105491). Sebelumnya, tanaman padi tersebut telah diketahui bersifat tahan tungro berdasarkan pengujian dengan galur tungro Bogor, Sumedang dan Bali menggunakan varietas pembanding Utri Merah yang tahan dan TN1 yang rentan (Tabel 1).

Pengujian ketahanan dilakukan sesuai standar international rice testing nursery menurut IRRI (1996). Setiap tanaman uji ditanam 2 baris dengan 10 bibit per baris dan di antaranya ditanam varietas pembanding. Setelah bibit berumur 2 minggu diinfestasi 2 ekor serangga wereng hijau per tanaman yang sebelumya telah melalui periode makan akuisisi selama 24 jam pada sumber inokulum virus tungro. Pengamatan gejala dilakukan pada 15 dan 30 hari setelah inokulasi terhadap penghambatan tinggi tanaman, insidensi dan keparahan penyakit. Pengamatan insidensi penyakit tungro dilakukan pada semua rumpun tanaman, dan tingkat keparahan penyakit menggunakan standard evaluation system for rice (SESR) (IRRI 1996).

\section{Ekstraksi DNA}

Isolasi total DNA daun padi dilakukan dengan metode yang diadopsi dari Pitch dan
Schubert (1993). Sampel daun sehat diambil dari tanaman yang berumur 1 minggu setelah semai. Daun dipotong kecil-kecil dan digerus hingga lumat menggunakan mortar yang telah didinginkan. Ekstrak daun disuspensikan dengan $1000 \mu \mathrm{L}$ bufer ekstraksi $(0.05 \mathrm{M}$ Tris- $\mathrm{HCl}, 0.05 \mathrm{M}$ EDTA, $0.5 \mathrm{M} \mathrm{NaCl}, \mathrm{pH} 8$ ), $100 \mu \mathrm{L}$ SDS $10 \%$ dan $100 \mu \mathrm{L}$ polyvinyl pyrolidone (PVP) 10\% di dalam tabung dan diinkubasi pada suhu $65^{\circ} \mathrm{C}$ selama 30 menit. Selanjutnya, ditambahkan $120 \mu \mathrm{L}$ potassium asetat $5 \mathrm{M} \mathrm{pH} 5.5$ dan suspensi daun diinkubasi di dalam es selama 30 menit sebelum disentrifugasi pada kecepatan 10000 rpm selama 15 menit. Supernatan dipindahkan ke tabung yang baru dan ditambahkan $800 \mu \mathrm{L}$ larutan kloroform dan isoamilalkohol dengan perbandingan 24:1. Tabung dibolakbalikkan hingga larutan tercampur merata dan disentrifugasi kembali. Supernatan lapisan atas dipindahkan ke tabung baru dan ditambahkan etanol absolut dingin sebanyak $2 \times$ lipat volume supernatan. Setelah diinkubasi selama \pm 1 jam di dalam lemari pendingin $\left(-20^{\circ} \mathrm{C}\right)$, supernatan disentrifugasi pada kecepatan $10000 \mathrm{rpm}$ selama 15 menit hingga DNA terendapkan pada bagian bawah tabung. Supernatan dibuang dan pelet DNA ditambahkan $800 \mu \mathrm{L}$ etanol 70\% lalu disentrifugasi kembali dengan kecepatan 10000 rpm selama 15 menit. Supernatan kemudian dibuang dan pelet DNA dikeringanginkan selama \pm 1 jam sebelum diresuspensi dengan $50 \mu \mathrm{L} \quad \mathrm{ddH}_{2} \mathrm{O}$ untuk digunakan sebagai templat PCR.

\section{Perancangan Primer}

Gen eIF4G (no. aksesi BAD30897) berukuran $5571 \mathrm{pb}$ yang terdiri atas 5 ekson $(4503 \mathrm{pb})$ dan 4 intron $(1068 \mathrm{pb})$ (NCBI 2015). Ekson sepanjang 4503 pb mengkode protein eIF4G yang terdiri atas 1501 asam amino. Pasangan primer SF (5'-ATTGTTGCCTCAGAGAGTCTTG-3') (posisi nt 2144-2166) dan SR (5'-GGACTTGGTGATCAACAACTT-3') (posisi nt 2439-2418) dirancang dari runutan gen ketahanan pada Utri Merah. Letak primer pada ekson ke-3 dari gen eIF4G diantara posisi nukleotida 2144-2439 (Gambar 1a). 
Ekspektasi DNA hasil amplifikasi adalah $\pm 294 \mathrm{pb}$ ( $\sim 300 \mathrm{pb}$ pada elektroforesis), mengkodekan 98 asam amino pada posisi asam amino 721-818 dari protein eIF4G (Gambar 1b).

\section{Amplifikasi Gen eIF4G}

Amplifikasi gen eIF4G dengan PCR menggunakan pasangan primer spesifik SF dan SR. Reaksi PCR dilakukan pada volume total $20 \mu \mathrm{L}$ yang mengandung $1 \mu \mathrm{L}$ bufer PCR $10 \times$, $1.5 \mu \mathrm{L} \mathrm{MgCl}_{2} 50 \mathrm{mM}, 0.5 \mu \mathrm{L}$ dNTP $10 \mathrm{mM}$, primer forward dan reverse $100 \mathrm{nM}$ masingmasing $1 \mu \mathrm{L}, 1 \mu \mathrm{L}$ DNA $200 \mathrm{ng}, 0.5 \mu \mathrm{L}$ Taq polymerase $\left(5 \mathrm{U} \mu \mathrm{L}^{-1}\right)$, dan $\mathrm{ddH}_{2} \mathrm{O}$ sampai volume total reaksi $20 \mu \mathrm{L}$. Proses amplifikasi gen dengan program PCR sebanyak 30 siklus dilakukan sebagai berikut, pradenaturasi pada suhu $94{ }^{\circ} \mathrm{C}$ selama 10 menit, denaturasi pada suhu $94{ }^{\circ} \mathrm{C}$ selama 1 menit, aneling pada suhu $60{ }^{\circ} \mathrm{C}$ selama 45 detik, pemanjangan pada suhu $72{ }^{\circ} \mathrm{C}$ selama 1 menit, dan pasca pemanjangan primer pada suhu $72{ }^{\circ} \mathrm{C}$ selama 10 menit. Hasil amplifikasi gen dielektroforesis dalam larutan bufer TAE dengan tegangan 90 volt selama 30 menit, lalu pita DNA divisualisasi menggunakan $U V$ Transilluminator setelah direndam dalam larutan etidium bromida $0.1 \%(\mathrm{w} / \mathrm{v})$ selama 15 menit.

\section{Perunutan DNA.}

Pita DNA hasil PCR berukuran $\sim 300 \mathrm{pb}$ diisolasi dari gel agarosa dan dipurifikasi menggunakan kit Agarose Gel DNA
Extraction (Qiagen, USA) sesuai protokol. DNA hasil purifikasi dirunut di First Base di Singapura. Pita DNA yang dirunut berasal dari hasil amplifikasi DNA var. Inpari HDB, Inpari Blas dan O. rufipogon menggunakan primer SF dan SR.

\section{Analisis in silico}

Analisis in silico runutan DNA dilakukan dengan aplikasi online. Analisis tingkat kesetaraan runutan dilakukan menggunakan database dalam server NCBI BLAST (http:// www.ncbi.nlm.nih.gov). Analisis multiple aligment dilakukan dengan server ClustalW (http://www.ch.embnet.org/software/ ClustalW.html) dan Boxshade (http://www. ch.embnet.org/software/BOX_form.html), sedangkan analisis motif dan domain protein dilakukan menggunakan sejumlah aplikasi yang tersedia di Exspassy tools (http://www. expasy.org/tools).

\section{HASIL}

Respons ketahanan var. Inpari HDB, Inpari Blas dan O.rufipogon terhadap infeksi 3 isolat tungro menunjukkan respons tahan jika dibandingkan dengan TN1 (Tabel 1).

Hasil PCR menunjukkan bahwa pasangan primer SF/SR berhasil mengamplifikasi fragmen DNA gen eIF4G dari genom padi var. Inpari HDB, Inpari Blas, O. rufipogon, dan Utri Merah, kecuali TN1. Produk PCR berupa pita tunggal DNA yang berukuran $\sim 300 \mathrm{pb}$
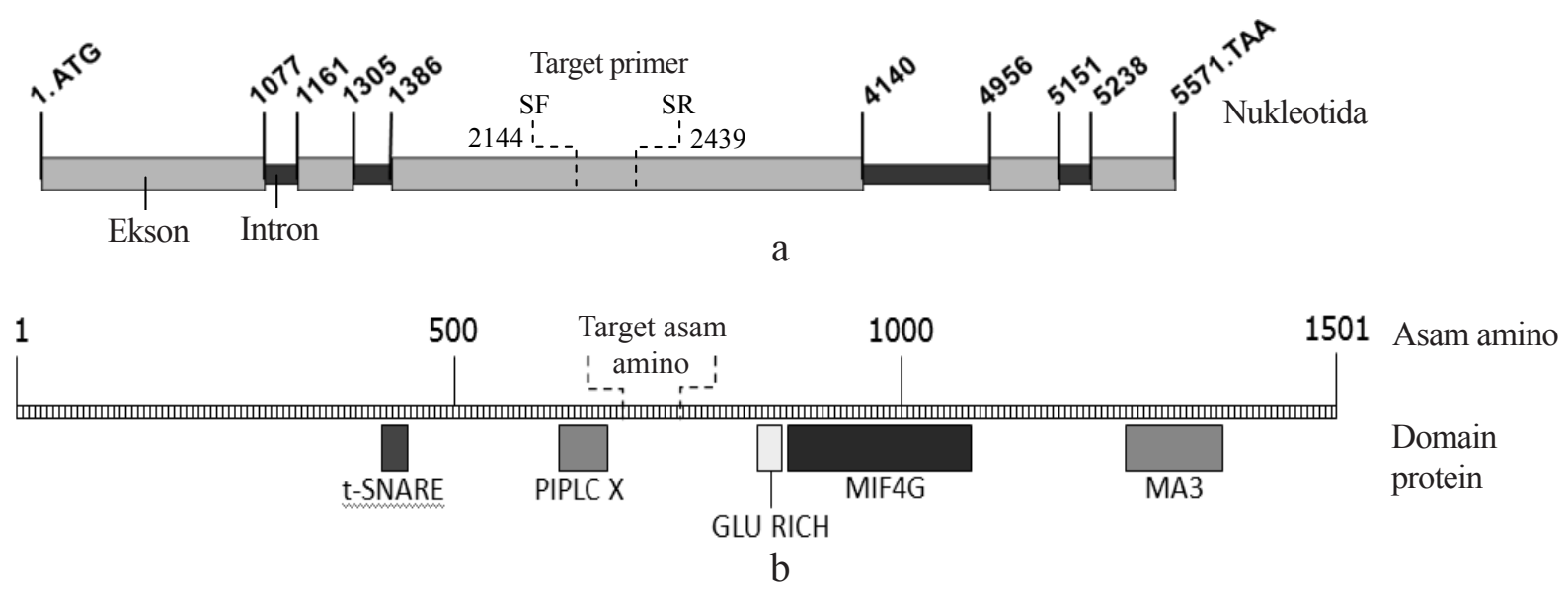

Gambar 1 a. Skematika gen eIF4G dan; b, protein eIF4G dari O. sativa grup Japonica (No. akasesi BAD30897). 
sesuai dengan ekspektasi ukuran DNA target (Gambar 2).

Analisis runutan DNA gen eIF4G terhadap basis data gen di Genbank dengan BLAST menunjukkan bahwa fragmen tersebut merupakan runutan nukleotida parsial dari gen eIF4G dengan tingkat homologi 93\% terhadap gen var. Utri Merah, NIL TW16 (turunan Utri Merah), var. TN1, dan $O$. sativa group Japonica (Tabel 2). Tingkat homologi gen tersebut di antara Inpari HDB, Inpari Blas dan O. rufipogon mencapai $100 \%$.

Hasil analisis penyejajaran menunjukkan bahwa gen eIF4G dari Inpari HDB dan Inpari Blas tidak berbeda dengan gen eIF4G dari O. rufipogon. Hal ini mengonfirmasi bahwa gen eIF4G pada Inpari HDB dan Inpari Blas berasal dari $O$. rufipogon yang menjadi salah satu tetuanya (Gambar 3; Gambar 4). Fragmen tersebut diduga bukan dari IR64 yang juga merupakan tetua Inpari HDB dan Inpari Blas karena pasangan primer SF/SR tidak mampu mengamplifikasi gen tersebut dari genom IR64 (Data tidak ditampilkan).

Perbandingan antara Utri Merah dan $O$. japonica, dengan gen eIF4G O. rufipogon menunjukkan ada 4 delesi nukleotida; 3 nukleotida pada posisi 2173-2175 dan 1 nukleotida pada posisi 2428-2429 dan 16 titik mutasi pada runutan nukleotida. Hal ini menyebabkan delesi 1 asam amino dan perbedaan 4 asam amino pada kedua varietas inpari dan O. rufipogon (Gambar 3; Gambar 4). Protein eIF4G $O$. rufipogon mengalami delesi asam amino serin (S) posisi 671 dan mutasi alanin/valin (A/V) posisi 673, treonin/alanin (T/A) posisi 723, glutamine/prolin (Q/P) posisi 742 , dan isoleusin/prolin (I/V) posisi 754 (Gambar 4).

\section{PEMBAHASAN}

Gen ketahanan tungro pada $O$. rufipogon sudah lama dilaporkan (Shibata et al. 2007) dan digunakan sebagai sumber gen dalam perakitan varietas tahan tungro, seperti Matatag di Filipina (Khush et al. 2004), Inpari HDB, dan Inpari Blas Indonesia (Manzila et al. 2013), tetapi gen yang berperan terhadap sifat ketahanan tersebut belum diketahui. Hasil penelitian menunjukkan bahwa gen eIF4G diduga menjadi salah satu gen penting yang berperan pada sifat ketahanan terhadap tungro pada $O$. rufipogon yang telah diturunkan pada kedua varietas padi tersebut. Fragmen gen ini sama dengan yang telah dilaporkan oleh Lee et al. (2010) pada Utri Merah, tetapi tingkat homologinya 93\%. Ditemukan ada dilesi dan sejumlah perbedaan nukleotida tunggal pada gen eIF4G $O$. rufipogon dibandingkan dengan eIF4Gtsv1 dari Utri Merah dan O. japonica.

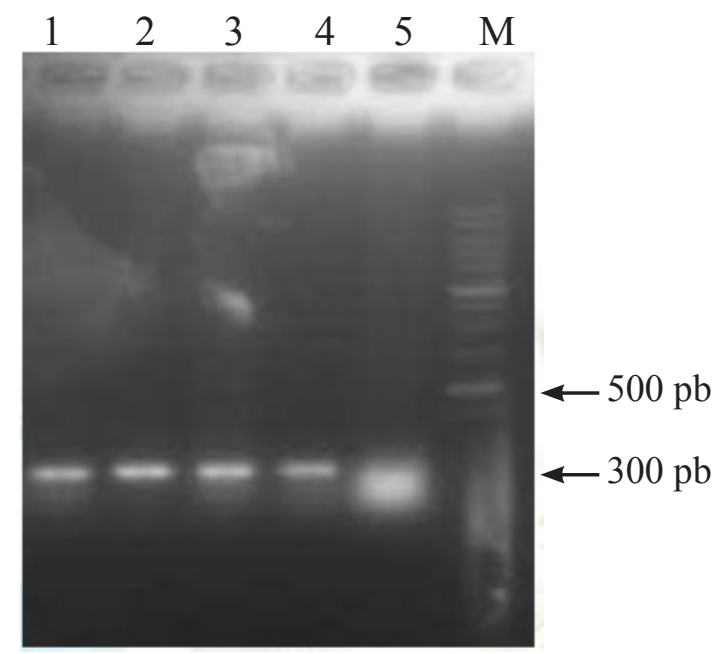

Gambar 2 Hasil elektroforesis gen eIF4G yang diampilifikasi dengan pasangan primer SF dan SR pada gel agarosa. M, Marker $100 \mathrm{pb}$; 1, Inpari HDB; 2, Inpari Blas; 3, Uthri Merah; 4, Oryza rufipogon; 5, TN1.

Tabel 1 Skor keparahan penyakit tungro pada var. Inpari HDB dan Inpari Blas

\begin{tabular}{lcccc}
\hline \multirow{2}{*}{ Varietas } & \multicolumn{3}{c}{ Isolat tungro } & \multirow{2}{*}{ Reaksi } \\
\cline { 2 - 4 } & Sumedang & Bogor & Bali & \\
\hline Inpari HDB & 1.0 & 0.8 & 2.6 & Tahan \\
Inpari Blas & 1.0 & 1.6 & 1.2 & Tahan \\
Utri Merah & 1.0 & 1.0 & 1.0 & Tahan \\
Oryza rufipogon & 1.0 & 1.0 & 1.0 & Tahan \\
TN1 & 8.6 & 8.6 & 7.8 & Rentan \\
\hline
\end{tabular}


Tabel 2 Analisis nukleotida gen ketahanan dari padi varietas Inpari HDB, Inpari Blas, dan O. rufipogon menggunakan program BLAST N

\begin{tabular}{clc}
\hline No. Aksesi & \multicolumn{1}{c}{ Deskripsi } & $\begin{array}{c}\text { Identitas } \\
\text { maksimum }\end{array}$ \\
\hline GQ203289 & $\begin{array}{l}\text { Runutan parsial CDS gen eukaryotic translation initiation factor } \\
\text { 4g dari Oryza sativa grup Indica (Utri Merah 16682) }\end{array}$ & $93 \%$ \\
GQ203290 & $\begin{array}{l}\text { Runutan parsial CDS gen eukaryotic translation initiation factor } \\
\text { 4g dari Oryza sativa grup Indica (Kultivar TW16) }\end{array}$ & $93 \%$ \\
GQ203288 & $\begin{array}{l}\text { Runutan parsial CDS gen eukaryotic translation initiation factor } \\
\text { 4g dari Oryza sativa grup Indica (Taichung Native 1) }\end{array}$ & $93 \%$ \\
BAD30897 & $\begin{array}{l}\text { Putative eukaryotic translation initiation factor 4G dari Oryza } \\
\text { sativa grup Japonica }\end{array}$ & $93 \%$ \\
AK069301 & Oryza sativa Japonica grup cDNA clone: J023014L06 & $93 \%$ \\
\hline
\end{tabular}

Inpari Blas

O. rufipogon

Inpari $\mathrm{HDB}$

Utri Merah (GQ203289)

O. japonica (BAD30897)

Inpari Blas

O. rufipogon

Inpari $\mathrm{HDB}$

Utri Merah (GQ203289)

O. japonica (BAD30897)

Inpari Blas

O. rufipogon

Inpari $\mathrm{HDB}$

Utri Merah (GQ203289)

O. japonica (BAD30897)

Inpari Blas

O. rufipogon

Inpari $\mathrm{HDB}$

Utri Merah (GQ203289)

O. japonica

Inpari Blas

O. rufipogon

Inpari $\mathrm{HDB}$

Utri Merah (GQ203289)

o. japonica (BAD30897)

Inpari Blas

O. rufipogon

Inpari $\mathrm{HDB}$

Utri Merah (GQ203289)

O. japonica (BAD30897)

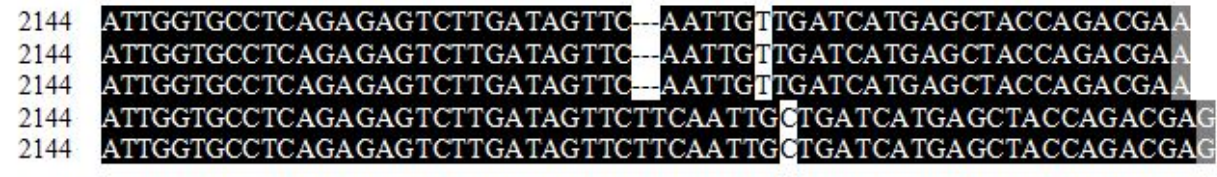

2204 TCCTCTGCAAAGGAGGCTAATATGGGTGAGGACGAGGGAAAGAAAAAGGTTGAGCTTGAT 2204 TCCTCTGCAAAGGAGGCTAATATGGGTGAGGACGAGGGAAAGAAAAAGGTTGAGCTTGAT 2204 TCCTCTGCAAAGGAGGCTAATATGGGTGAGGACGAGGGAAAGAAAAAGGTTGAGCTTGAT 2204 TCCTCCGAAAAGGAGGTTAATATGGGTGAGGACGAGGGAAAGAAAAAGGTTGAGCTTGAT 2204 TCCTCCGAAAAGGAGGTTAATATGGGTGAGGACGAGGGAAAGAAAAAGGTTGAGCTTGAT

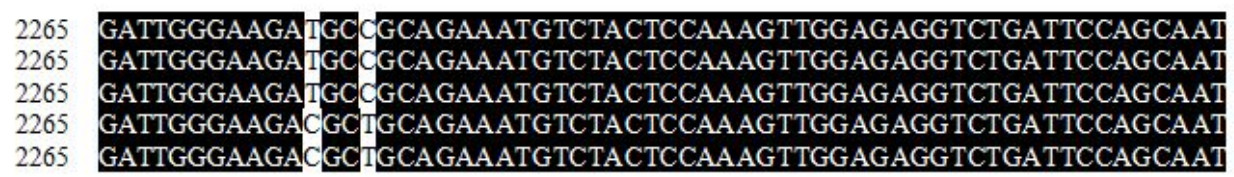

2265 GATTGGGAAGACGCTGCAGAAATGTCTACTCCAAAGTTGGAGAGGTCTGATTCCAGCAAT
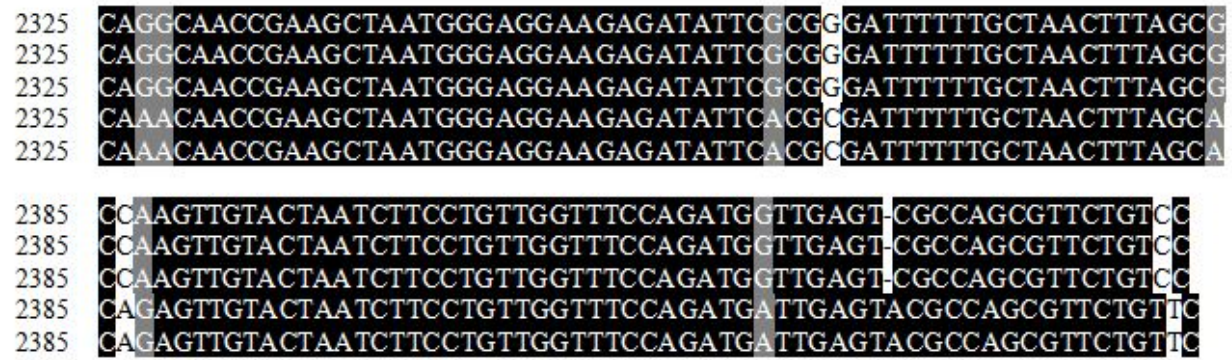

2445 CCTACTGCGTTTTTC

2445 CCTACTGCGTTTTTC

2445 CCTACTGCGTTTTTC

2445 CCTA-..-..-..-

2445 CCTA

Gambar 3 Hasil analisis penyejajaran runutan nukleotida gen eIF4G dengan software Clustal W.

INPARI BLAS

O. rufinogon

INPARI HDB

Utri Merah (GQ203289)

O. japonica (BAD30897)

INPARI HDB

O. rufipogon

INPARI HDB

Utri Merah (GQ203289)

O. japonica (BAD30897)
660 FIGASESLDSS-IVDHELPDESSEKEVNMGEDEGKKK VELDDWEDAAEMSTPKLERSDSS 660 FIGASESLDSS-IVDHELPDESSEKEVNMGEDEGKKK VELDDWEDAAEMSTPKLERSDSS 660 FIGASESLDSS-IVDHELPDESSEKEVNMGEDEGKKKVELDDWEDAAEMSTPKLERSDSS 660 FIGASESLDSSSIADHELPDESSEKEVNMGEDEGKKKVELDDWEDAAEMS TPKLERSDSS 660 FIGASESLDSS-IVDHELPDESSEKEVNMGEDEGKKK VELDDWEDAAEMSTPKLERSDSS

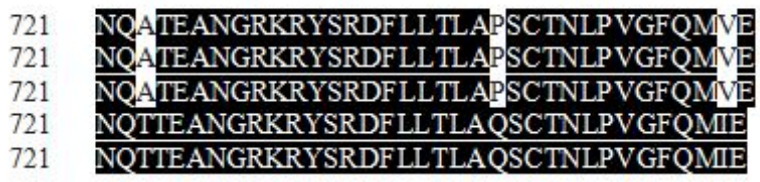

Gambar 4 Hasil analisis penyejajaran runutan asam amino protein eIF4G dengan software Clustal W. 
Gen eIF4G merupakan house keeping gene yang ada pada semua organisme eukariot (Patrick and Browning 2012). Peran utama protein yang dikodekan oleh gen eIF4G di dalam sel tumbuhan ialah untuk menginisiasi proses translasi protein dan pengaturan ekspresi sejumlah gen (Marintchev dan Wagner 2005). Protein eIF4G diperlukan oleh mRNA untuk membentuk ikatan dengan subunit ribosomal 40S dan memindai 5'-untranslated region mRNA hingga ditemukannya start codon. Tetapi sejumlah virus dilaporkan memanfaatkan eIF4G untuk proses translasi dan ekspresi genomnya dalam melengkapi proses siklus hidup dan infeksi inangnya (Hwang et al. 2013). Sebagai parasit obligat dengan struktur partikel yang sangat sederhana, virus tidak memilki kelengkapan organel untuk bisa hidup secara mandiri sehingga harus tergantung pada inang (Nagy dan Pogany 2011). Untuk melengkapi keseluruhan siklus hidupnya, virus patogen dari genus Potyvirus menggunakan protein eIF4G untuk membantu proses transkripsi dan translasi genomnya. Menurut Lellis et al. (2002) ada 3 mekanisme pemanfaatan protein eIF4G oleh virus patogen, yaitu inisiasi proses translasi, stabilisasi genom virus, dan proses lalu lintas partikel virus di dalam sel (intracellular trafficking).

Mutasi pada gen eIF4G O. rufipogon diduga menyebabkan perubahan interaksi antara RTSV dengan inangnya. Virus patogen tidak mampu lagi mengenali protein eIF4G inang yang menjadi target untuk membantu dalam proses infeksinya. Albar et al. (2006) melaporkan polimorfisme nukleotida tunggal pada gen RMYV1 yang mengodekan eIF(iso)4G dari padi $O$. sativa Gigante dan $O$. glaberima yang tahan terhadap Rice yellow mottle virus (RYMV) dibandingkan tanaman yang rentan. Pada Arabidopsis thaliana, mutasi pada gen eIF4G $\mathrm{G}^{\text {cum2 }}$ mengakibatkan $\mathrm{CMV}$ tidak mampu bereplikasi meski mutasinya hanya berupa substitusi (Yoshii et al. 2004)

Protein eIF4G dari $O$. sativa Japonica (no. aksesi BAD30897) memiliki 5 domain utama, yaitu middle portion of eIF4G (MIF4G), methyl adenine (MA-3), Phosphatidylinositol-specific phospholipase X-box (PIPLC-X), t-SNARE coiled-coil homology (T_SNARE) dan GLU_RICH Glutamic acid-rich (GLU-Rich) (Sasaki et al. 2002). Dua domain terpanjang ialah MIF4G pada posisi asam amino 8921115 yang berfungsi untuk mengikatkan RNA dengan protein eIF4A dan MA-3 pada posisi asam amino 1313-1427 yang merupakan situs pengikatan kedua. Tetapi fragmen gen yang berhasil diamplifikasi dengan primer SF/SR berada diluar 5 domain tersebut dan memiliki motif protein yang terkait dengan fosforilasi kinase (serin/treonin) dan Arg-GlyAsp (RGD)-cell attachment. Motif fosforilasi kinase enzim kinase dalam mengkatalis reaksi fosforilasi terhadap jenis protein tertentu pada residu serina/treonina termasuk faktor transkripsi yang terdapat pada inti sel (Zhao et al. 2007). Motif Arg-Gly-Asp (RGD)cell attachment berfungsi mengenali reseptor integrin dalam proses interaksi sel patogen

Berdasarkan penelitian ini, gen eIF4G berhasil dideteksi dan diidentifikasi dari varietas Inpari $\mathrm{HDB}$, Inpari Blas dan $O$. rufipogon dengan homologi nukleotida gen parsial mencapai $100 \%$. Gen ini diduga kuat berperan dalam sifat ketahanan kedua varietas terhadap infeksi RTSV. Namun belum diketahui mekanisme gen eIF4G yang terdelesi dan ada polimorfisme nukleotida tunggal mampu menghambat infeksi RTSV, sebagai salah satu penyebab penyakit tungro pada varietas Inpari HDB dan Inpari Blas. Selain itu belum diketahui apakah gen eIF4G menjadi satu-satunya gen yang berperan terhadap sifat ketahanan terhadap tungro atau ada peran gen-gen lainnya, sehingga sifat durability ketahanan Inpari HDB dan Inpari Blas dapat diketahui. Oleh karena itu kajian yang lebih mendalam perlu dilakukan untuk mengetahui peran penting gen tersebut.

\section{UCAPAN TERIMA KASIH}

Penelitian ini dibiayai dari DIPA Balai Besar Penelitian dan Pengembangan Bioteknologi dan Sumber Daya Genetik Pertanian (BBBiogen) TA. 2015 dengan nomor DIPA 1798.001.003. Terima kasih disampaikan 
kepada Ida Hanarida Soemantri dan Dwinita Wikan Utami yang telah memberikan material penelitian.

\section{DAFTAR PUSTAKA}

Albar L, Bangratz-Reyser M, Hèbrard E, Ndjiondjop $\mathrm{MN}$, Jones $\mathrm{M}$, Ghesquière A. 2006. Mutations in the eIF(iso) $4 \mathrm{G}$ translation initiation factor confer high resistance of rice to Rice yellow mottle virus. Plant J. 47: 417-426. DOI: http://dx.doi. org/10.1111/j.1365-313X.2006.02792.x.

Angeles ER, Cabunagan RC, Tabien RE, Khush GS. 2008. Resistance to tungro vectors and viruses. Di dalam: Tiongco ER, Angeles ER, Sebastian LS, editor. Rice Tungro Virus Disease: A Paradigm in Disease Management. Science City of Munoz, Nueva Ecija (PH): Philippine Rice Research Institute and Honda Research Institute Japan Co. Ltd. hlm 117-141.

Balai Besar Padi. 2010. Laporan tahunan hasil penelitian. Sukamandi (ID). Balai Besar Padi.

Choi IR, Cabauatan PQ, Cabunagan RC. 2009. Rice Tungro Disease. Rice Fact Sheet, IRRI, Sep. 2009: 1-4.

Cruz FCStA, Boulton MI, Hull R, Azzam O. 1999. Agroinoculation Allows the Screening of Rice for Resistance to Rice Tungro Bacilliform Virus. J Phytopathol. 147(11-12):653-659. DOI: http://dx.doi. org/10.1046/j.1439-0434.1999.00452.x.

Darajat AA, Widiarta IN, Jumanto H. 2004. Prospek perbaikan varietas padi tahan virus tungro dan serangga wereng hijau. Di dalam: Prosiding Seminar Nasional Status Program Penelitian Tungro Mendukung Keberlanjutan Produksi Padi Nasional; Sept 7-8 2004; Makassar (ID): Pusat Puslitbangtan, Badan Litbang Pertanian. Hlm 27-35.

[Ditlin] Direktorat Perlindungan Hortikultura. 2015. Luas serangan OPT utama pada tanaman padi. www.tanamanpangan. pertanian.go.id. [diakses tanggal 1 Juni 2015.].

Ladja FT, Widiarta IN. 2012. Varietas unggul baru padi untuk mengantisipasi ledakan penyakit tungro. Iptek Tan Pangan. 7(1):18-24.

German-Retana S, Walter J, Le Gall O. 2008. Lettuce mosaic virus: from pathogen diversity to host interactions. Mol Plant Pathol. 9: 127-136. DOI: http://dx.doi. org/10.1094/MPMI.2001.14.6.804.

Hwang JN, Chang SO, Kang BC. 2013. Translation elongation factor $1 \mathrm{~B}(\mathrm{eEF} 1 \mathrm{~B})$ is an essential host factor for Tobacco mosaic virus infection in plants. Virology. 439: 105-114. DOI: http://dx.doi.org/10.1016/j. virol.2013.02.004.

IRRI. 1996. Standard evaluation system for rice. Los Banos (PH): IRRI.

Kang BC, Yeam I, Jahn MM. 2005. Genetics of plant virus resistance. Annu Rev Phytopathol. 43:581-621. DOI: http://dx.doi.org/10.1146/annurev. phyto.43.011205.141140.

Kobayashi N, Ikeda R, Vaughan DA. 1993. Resistance to rice tungro viruses in wild species of rice (Oryza spp.). Jpn J Breed. 43:247-255. DOI: http://dx.doi. org/10.1270/jsbbs1951.43.247.

Khush GS, Angeles E, Virk PS, Brar DS. 2004. Breeding rice for resistance to tungro virus at IRRI SABRAO. J Breed Gen. 6(2):101-106.

Lee JH, Muhsin M, Atienza GA, Kwak DY, Kim SM, De Leon TB, Angeles ER, Coloquio E, Kondoh H, Satoh K, Cabunagan RC, Cabauatan PQ, Kikuchi S, Leung H, Choi IR. 2010. Single nucleotide polymorphisms in a gene for translation initiation factor (eIF4G) of rice (Oryza sativa) associated with resistance to Rice tungro spherical virus. Mol Plant Microb Interact. 23(1):29-38.DOI: http://dx.doi. org/10.1094/MPMI-23-1-0029.

Lellis AD, Kasschau KD, Whitham SA, Carrington JC. 2002. Loss-of-susceptibility mutants of Arabidopsis thaliana reveal an essential role for eIF(iso)4E during potyvirus infection. Curr Bio. 12:10461051. DOI: http://dx.doi.org/10.1016/ S0960-9822(02)00898-9.

Leonard S, Plante D, Wittmann S, Daigneault N, Fortin MG, Laliberte JF. 2000. Complex 
formation between potyvirus VPg and translation eukaryotic initiation factor $4 \mathrm{E}$ correlates with virus infectivity. J Virol. 74(17):7730-7737. DOI: http://dx.doi. org/10.1128/JVI.74.17.7730-7737.2000.

Manzila 1, TP Priyatno, I Hanarida. 2013. Ketahanan galur padi hibrida potensi hasil tinggi terhadap penyakit tungro. J Fitopatol Indones 9(3):77-83. DOI: http://dx.doi. org/10.14692/jfi.9.3.77.

Marintchev A, Wagner G. 2005. eIF4G and CBP80 share a common origin and similar domain organization: implications for the structure and function of eIF4G. Biochem 44(37):12265-12272. DOI: http://dx.doi. org/10.1021/bi051271v.

Miyoshi H, Suehiro N, Tomoo K, Muto S, Takahashi T, Tsukamoto T, Ohmori T, Natsuaki T. 2006. Binding analyses for the interaction between plant virus genomelinked protein $(\mathrm{VPg})$ and plant translational initiation factors. Biochimie. 88: 329340. DOI: http://dx.doi.org/10.1016/j. biochi.2005.09.002.

Nagy PD, Pogany J. 2011. The dependence of viral RNA replication on co-opted host factors. Nat Rev Microbiol. 10(2):137149. DOI: http://dx.doi.org/10.1038/ nrmicro2692.

Patrick RM, Browning KS. 2012. The eIF4F and eIFiso4F complexes of plants: an evolutionary perspective. Com Funct Genom. 12:1-12. DOI: http://dx.doi. org/10.1155/2012/287814.

Pitch U, Schubert I. 1993. Midiprep method for isolation of DNA from plants with high content of polyphenolics. Nucleic Acids Res. 21: 3328. DOI: http://dx.doi. org/10.1093/nar/21.14.3328.

Sasaki T, Matsumoto T, Katayose Y. 2002. Oryza sativa Nipponbare (GA3) genomic DNA, chromosome 7, BAC clone: OSJNBa0058I18. http://www.ncbi.nlm. nih.gov/protein/BAD30897 [diakses 10 Jul 2015].

Shibata Y, Cabunagan RC, Cabauatan PQ, Choi IR. 2007. Characterization of Oryza rufipogon-derived resistance to tungro disease in rice. Plant Dis. 91(11): 13861391. DOI: http://dx.doi.org/10.1094/ PDIS-91-11-1386.

Yeam I, Cavatorta JR, Ripoll DR, Kang BC, Jahn MM. 2007. Functional dissection of naturally occurring amino acid substitutions in eIF4E that confers recessive potyvirus resistance in plants. Plant Cell. 19(9):2913-2928. DOI: http:// dx.doi.org/10.1105/tpc.107.050997.

Yoshii M, Nishikiori M, Tomita K, Yoshioka N, Kozuka R, Naito S, Ishikawa M. 2004. The Arabidopsis Cucumovirus Multiplication 1 and 2 loci encode translation initiation factors 4E and 4G. J Virol. 78(12):61026111. DOI: http://dx.doi.org/10.1128/ JVI.78.12.6102-6111.2004.

Zhao X, Mehrabi R, Xu JR. 2007. Mitogenactivated protein kinase pathways and fungal pathogenesis. Eukar Cell. 6(10): 1701-1714. DOI: http://dx.doi. org/10.1128/EC.00216-07. 